\title{
PARASITOFAUNA OF ALLOCHTHONOUS FISH SPECIES IN THE OPEN WATERS OF THE DANUBE RIVER BASIN (SERBIAN PART) - IMPACT ON THE NATIVE FISH FAUNA
}

\author{
DJIKANOVIĆ, V. ${ }^{1 *}$ - SimONOVIĆ, P. $^{2}$ - CAKIĆ, P. ${ }^{1}$ - NiKOLIĆ, V. ${ }^{2}$ \\ ${ }^{1}$ Institute for Biological Research "Sinisa Stankovic", University of Belgrade \\ 142 Bulevar Despot Stefan, 11060 Belgrade, Serbia \\ (e-mail:djiki@ibiss.bg.ac.rs; cakic@ibiss.bg.ac.rs) \\ ${ }^{2}$ Institute for Zoology, Faculty of Biology, University of Belgrade \\ Studentski trg 16, 11000 Belgrade, Serbia \\ (e-mail:pedja@bio.bg.ac.rs; vera@bio.bg.ac.rs) \\ *Corresponding author \\ e-mail:djiki@ibiss.bg.ac.rs; phone: +381-11-207-8357 \\ (Received $4^{\text {th }}$ Jul 2018; accepted $14^{\text {th }}$ Aug 2018)
}

\begin{abstract}
In this review data on parasitofauna of allochthonous fish species in the Danube River Basin in Serbia is presented. Up to now, 33 ecto- and endoparasites of seven examined allochthonous invasive fish species have been reported. Some of the identified parasitic species are new for fish parasitofauna in the Serbian waters (Trichodina nobilis, Balantidium sp., Philometroides cyprini, Philometroides parasiluri, Eustrongylides sp., Ergasilus sieboldi, Lernaea cyprinacea, Sinergasilus polycolpus). In the open waters of Serbia (the Danube River Basin) a total of 26 non-indigenous fish species were recorded, of which 16 were the allochthonous invasive fishes. The major means of introductions and translocations were found to be the aquaculture, fish stocking and transportation. Habitat modification was found to be the factor that largely contributes to the capability of the water bodies to become a suitable recipient area. The large presence of alien fish species $(27.66 \%)$ and its parasites creates a serious threat to the stability of freshwater ecosystems and the survival of the native ichthyofauna. The main environmental consequences of alien fish spreading are related to the alteration in fish community structure and function, as well as the introduction of the alien parasite species.
\end{abstract}

Keywords: parasites, alien fish, alteration in fish community, Danube, Serbia

\section{Introduction}

The introduction of fish specimens into aquatic ecosystems is common around the world. The main purpose of these introductions over the past three decades is for aquaculture, reinforcement of natural populations, biological control or recreation activities (exotic fish aquaria, angling, etc.) (Welcomme, 1981, 1988; Stewart, 1991). Ballast water of ships, deliberate fish stocking and introduction into aquaculture were pointed as prospective agents of dispersal of non-indigenous fish species in aquatic ecosystems (Gherardi et al., 2009).

Alien fishes have been introduced for many reasons in Europe: ornament, sport, improvement of wild stocks, aquaculture, biological control and accident (Elvira, 2001).

Aquatic introductions are made possible by a range of factors, including speciesspecific traits as well as by human activities such as river regulation, the connection of bordering basins by canals or ballast transport (Grigorovich et al., 2003). The success of introduction depends on the capability of species to avoid predators and parasites (Torchin et al., 2003). According to that, introduced species attain higher population densities and greater individual sizes in the recipient areas as compared to nonspecific 
in their native range (Torchin et al., 2001). Non-indigenous species may affect indigenous species by competing for resources, transferring pathogens, or significantly altering the habitat. The introduction of non-indigenous species may work synergistically with some factors, such as water pollution, to alter the population and distribution of indigenous species (Elvira, 2001). The main environmental consequences of alien fish spreading are related to the alteration in fish community structure and function, as well as the introduction of the non-indigenous parasite fauna. Despite the importance of host manipulation by parasites for ecosystems and health, the effects of environmental changes on their ecological roles are largely ignored (Labaude et al., 2015). In contrast to other ecological effects, the importation of parasites, pathogens and diseases can be made via alien fish never intended to be released into the wild. Many diseases of salmonids that infect hatchery-reared fish and also occur in wild populations have been imported. Rainbow trout Oncorhynchus mykiss (Walbaum, 1792) from the western part of North America has carried furunculosis to Europe (Borno and Colquhoun, 2009). The importation of pathogens that are not group specific is a great risk associated with the introduction of exotic species (Elvira, 2001).

The consequences of biotic invasions are diverse and interconnected, since invaders can alter fundamental ecological properties such as dominant species in a community, productivity, nutrient cycling and thus can alter the structure and function of the ecosystem (Mack et al., 2000). Also, when present in sympatry, invasive species have the potential to amplify or diminish their ecological impacts through their trophic interactions, like it is tested for Cyprinus carpio and Pseudorasbora parva (Jackson and Britton, 2014).

Aquatic ecosystems in Serbia, especially those settled in north, lowland district, are influenced by biological invasion and contamination. The Danube River is an important invasion corridor, so called "Southern Invasion Corridor" (Galil et al., 2007) highly suitable for introduction of invasive fish species in Serbian waters (Jankovic et al., 1987; Hegedis et al., 1991; Cakic et al., 1996, 2004; Maletin et al., 1997; Simonovic and Nikolic, 1997; Simonovic et al., 1998, 2001). Also, the role of hydro-morphological alterations in aquatic invasions in this region has already been shown in the case of introduction and acclimation of invertebrate and fish species (Jankovic et al., 1987; Lenhardt et al., 2011). Thus, the Iron Gate area, downstream stretches of the main tributaries of the Danube River (the Sava, the Tisa and the Velika Morava River), that are under the influence of hydro-morphological changes, as well as artificial channel network Danube-Tisa-Danube, seemed to be suitable recipient areas for introduction and population establishment of non-native taxa.

Non-native ichthyofauna in Serbia has mostly been investigated as the part of ecological or taxonomical studies of particular areas. The data on alien fish fauna within the Serbian part of the Danube River originated from a number of studies and monitoring programs (Cakic and Hristic, 1987; Maletin et al., 1997; Jankovic, 1998; Simonovic et al., 1998, 2001; Lenhardt et al., 2011; Zorić et al., 2014). Introduction of allochthonous species into Serbian waters were made primarily in order to increase ichthyoproduction for weed control, sport fishing purposes and also accidentally (Lenhardt et al., 2011).

The aim of the present study is to report parasitic species of allochthonous fish species in the Serbian waters in the period of the last 31 years, and to investigate their contribution to diversity of fish parasitofauna. 


\section{Materials and methods}

The study comprehends the data derived from several long-term investigations of freshwater fish species in the surface waters of the Danube River Basin in Serbia. During these studies, many allochthonous fish species have been identified and processed. Fish samples were collected using multi-mesh nets with mesh size of 10$60 \mathrm{~mm}$, as well as by electrofishing (HONDA $1.2 \mathrm{~kW}, 6 \mathrm{~A}$ ). After sampling, fish specimens were anesthetized in clove solution and sacrificed with a quick blow to the head. Fish species were identified according to Simonović (2006). The material of nonnative freshwater fishes was analyzed for ecto- and endoparasites using standard parasitological procedure. Squash slides were taken from the skin and gills and observed under a light microscope (400 x magnitudes) within two hours. The slides were impregnated with silver-nitrate according to the modified Klein-Feussner method. The collected parasites were preserved in $4 \%$ formaldehyde (Acantocephala, Digenea/Trematoda, Cestoda, Bivalvia), in a mixture of ammonium picrate and glycerin (Monogenea) or in a mixture of glycerin and alcohol (Nematoda). Metazoan parasites were bleached, stained, prepared and fixed for determination and collection. Isolation, sorting and identification of parasite fauna have been done in the laboratory. Appropriate identification keys were used for the determination of parasite fauna representatives to the lowest taxonomic level (Bykhovskaya-Pavlovskaya et al., 1962; Banina, 1984; Shulman and Jankovsky, 1984; Stein, 1984; Bauer, 1987; Lom and Dikova, 1992; Moravec, 1994).

\section{Results}

In total, 26 non-indigenous fish species from nine different families have been reported from the Serbian part of the Danube River basin area (Table 1), contributing to the total species richness of ichthyofauna of Serbia 27.66\%. Their parasitic species have been investigated and identified. In this paper, a total of 33 parasites (ecto- and endo-) are reported. The impact of those aliens on native fish is the topic for further research.

The list of allochthonous fish species, their status and occurrence in recipient area, pathway of introduction in our waters as well as their origin are presented (Table 1).

Table 1. Non-indigenous fish species (26) within the Danube River Basin in Serbia

\begin{tabular}{c|c|c|c|c}
\hline Taxa & ST & OC & MI & OR \\
\hline Fam. Polyodontidae & & & & \\
Polyodon spathula (Walbaum, 1792) & NN & R & AC & NA \\
Fam. Coregonidae & U & R & FS & E \\
Coregonus peled (Gmelin, 1789) & & & & \\
Fam. Salmonidae & NN & R & AC & NA \\
Salvelinus fontinalis (Mitchill, 1815) & NN & R & AC & E \\
Salvelinus alpinus (Linnaeus, 1758) & NN & F & AC & NA \\
Oncorhynchus mykiss (Walbaum, 1792) & N & R & FS & E \\
Salmo letnica (Karaman, 1924) & & & & \\
Fam. Cyprinidae & N & FA & AC & A \\
Pseudorasbora parva (Schlaegel, 1842) & N & FA & AC & A \\
Ctenopheryngodon idella (Valenciennes, 1844) & N & FA & AC & A
\end{tabular}


Hypophthalamichthys nobilis (Richardson, 1844)

Carassius gibelio (Bloch, 1783)

Alburnus albidus (Costa, 1838)

Pachychilon macedonicus (Steindachner, 1892)

Rutilus basak (Heckel, 1843)

Scardinius graecus Stephanidis, 1937

$\underline{\text { Fam. Ictaluridae }}$

Ameiurus nebulosus (Le Sueur, 1819)

Ameiurus melas (Rafinesque, 1820)

$\underline{\text { Fam. Centrarchidae }}$

Lepomis gibbosus (Linnaeus, 1758)

Micropterus salmonides (Lacepede, 1802)

Fam. Gobiidae

Neogobius melanostomus (Pallas 1811)

Neogobius fluviatilis (Pallas, 1811)

Ponticola kessleri (Gunther, 1861)

Babka gymnotrachelus (Kessler, 1857)

Proterorhinus semilunaris (Heckel, 1837)

Odontobutidae

Perccottus glenii (Dybowsky, 1877)

Fam. Syngnathidae

Syngnathus abaster (Risso, 1826)

\begin{tabular}{c|c|c|c}
$\mathrm{N}$ & $\mathrm{FA}$ & $\mathrm{AC}$ & $\mathrm{A}$ \\
$\mathrm{N}$ & $\mathrm{FA}$ & $\mathrm{FS}$ & $\mathrm{A}$ \\
$\mathrm{N}$ & $\mathrm{FA}$ & $\mathrm{FS}$ & $\mathrm{E}$ \\
$\mathrm{U}$ & $\mathrm{R}$ & $\mathrm{UC}$ & $\mathrm{E}$ \\
$\mathrm{U}$ & $\mathrm{R}$ & $\mathrm{FS}$ & $\mathrm{E}$ \\
$\mathrm{U}$ & $\mathrm{R}$ & $\mathrm{UC}$ & $\mathrm{E}$ \\
& & & \\
$\mathrm{N}$ & $\mathrm{FA}$ & $\mathrm{AC}$ & $\mathrm{NA}$ \\
$\mathrm{N}$ & $\mathrm{FA}$ & $\mathrm{AC}$ & $\mathrm{NA}$ \\
& & & \\
$\mathrm{N}$ & $\mathrm{FA}$ & $\mathrm{AC}$ & $\mathrm{NA}$ \\
$\mathrm{N}$ & $\mathrm{FA}$ & $\mathrm{FS}$ & $\mathrm{NA}$ \\
$\mathrm{N}$ & $\mathrm{FA}$ & $\mathrm{S}$ & $\mathrm{PC}$ \\
$\mathrm{N}$ & $\mathrm{FA}$ & $\mathrm{UC}$ & $\mathrm{PC}$ \\
$\mathrm{N}$ & $\mathrm{F}$ & $\mathrm{S}$ & $\mathrm{PC}$ \\
$\mathrm{N}$ & $\mathrm{F}$ & $\mathrm{S}$ & $\mathrm{PC}$ \\
$\mathrm{N}$ & $\mathrm{F}$ & $\mathrm{UC}$ & $\mathrm{PC}$ \\
$\mathrm{N}$ & $\mathrm{R}$ & $\mathrm{UC}$ & $\mathrm{A}$ \\
$\mathrm{N}$ & $\mathrm{FA}$ & $\mathrm{S}$ & $\mathrm{PC}$ \\
$\mathrm{N}$ & &
\end{tabular}

Status (ST) - N-Naturalized, NN-not naturalized, U-unknown. Occurrence (OC) - FA-frequent and abundant, F-frequent, R-rare or single findings. Means of Introduction (MI) - AC-aquaculture, FS-fish stocking, S-shipping, UC-unclear. Origin (OR) - PC-Ponto-Caspian, A-Asia, NA-North America, EEurope out of Ponto-Caspian Area

In Table 2 the list of parasitic species (14 ecto- and 19 endoparasites) are presented, in seven allochthonous invasive fish species from the Serbian part of the Danube River Basin. Among them, some of the identified parasitic species are new for fish parasitofauna in the Serbian waters (Trichodina nobilis, Balantidium sp., Philometroides cyprini, Philometroides parasiluri, Eustrongylides sp., Ergasilus sieboldi, Lernaea cyprinacea, Sinergasilus polycolpus) (marked *, see Table 2).

Table 2. Parasitic species (ecto-and endoparasitic species) of seven allochthonous invasive fish species, Danube River in Serbia

\begin{tabular}{c|c|c|c}
\hline $\begin{array}{c}\text { Taxonomy } \\
\text { group }\end{array}$ & Parasitic species & Fish host & Reference \\
\hline Eumycota & Saprolegnia sp & Oncorhynchus mykiss & Nikolic et al., 2010 \\
\hline Myxosporidia & Myxobolus sp. & Oncorhynchus mykiss & Cakic, 2002 \\
\hline \multirow{3}{*}{ Ciliophora } & \multirow{2}{*}{ Ichthyophthirius multifilis (Fouquet, 1876) } & Carassius gibelio & Nikolic and Simonovic, 1998a \\
& & Ameiurus nebulosus & Cakic, 2002 \\
\cline { 2 - 4 } & \multirow{2}{*}{ Chilodonella cyprini (Moroff, 1902) } & Carassius gibelio & Nikolic and Simonovic, 1998b \\
& & Ameiurus nebulosus & Nikolic and Simonovic, 1999a \\
\cline { 2 - 4 } & &
\end{tabular}




\begin{tabular}{|c|c|c|c|}
\hline & Chilodonella hexasticha (Kiernik, 1909) & $\begin{array}{c}\text { Carassius gibelio } \\
\text { Oncorhynchus mykiss }\end{array}$ & $\begin{array}{l}\text { Nikolic et al., } 2006 \\
\text { Nikolic et al., } 2006\end{array}$ \\
\hline & Trichodina nigra (Lom, 1960) & $\begin{array}{c}\text { Carassius gibelio } \\
\text { Ameiurus nebulosus }\end{array}$ & $\begin{array}{l}\text { Nikolic et al., } 2003 \\
\text { Nikolic et al., } 2003\end{array}$ \\
\hline & Trichodina nobilis (Chen, 1963)* & $\begin{array}{c}\text { Ctenopharyngodon idella } \\
\text { Hypophthalmichthys molitrix }\end{array}$ & $\begin{array}{l}\text { Nikolic and Simonovic, 1998a } \\
\text { Nikolic and Simonovic, 1998a }\end{array}$ \\
\hline & Trichodina acuta (Lom, 1961) & Ameiurus nebulosus & Nikolic et al., 2003 \\
\hline & Trichodina sp. & $\begin{array}{c}\text { Carassius gibelio } \\
\text { Oncorhynchus mykiss }\end{array}$ & $\begin{array}{l}\text { Nikolic et al., } 2003 \\
\quad \text { Cakic, } 2002\end{array}$ \\
\hline & Trichodinella epizootica (Raabe, 1950) & $\begin{array}{l}\text { Lepomis gibbosus } \\
\text { Ameiurus nebulosus }\end{array}$ & $\begin{array}{l}\text { Nikolic and Simonovic, 1999a,b } \\
\text { Nikolic and Simonovic, 1999a,b }\end{array}$ \\
\hline & Trichodinella subtilis (Lom, 1959) & Ameiurus nebulosus & Nikolic and Simonovic, 1999a,b \\
\hline & $\begin{array}{c}\text { Balantidium sp. (Claparède \& Lachmann, } \\
1858)^{*}\end{array}$ & Carassius gibelio & Cakic and Hristic, 1987 \\
\hline & $\begin{array}{l}\text { Apiosoma piscicola var. minor (Blanchard, } \\
1885 \text { ) }\end{array}$ & Oncorhynchus mykiss & Nikolic and Simonovic, 1999a \\
\hline & Apiosoma piscicola piscicola (Blanchard, 1885) & Ameiurus nebulosus & Nikolic and Simonovic, 1999b \\
\hline \multirow{2}{*}{ Monogenea } & Gyrodactylus derjavini (Mikailov, 1975) & Oncorhynchus mykiss & Nikolic and Simonovic, 1999b \\
\hline & Urocleidus similis (Mueller, 1936) & Lepomis gibbosus & Kiskaroly and Tafro, 1988 \\
\hline \multirow{2}{*}{ Digenea } & Diplostomum spathaceum (Nordmann, 1832) & Oncorhynchus mykiss & Nikolic and Simonovic, 1999b \\
\hline & Posthodiplostomum cuticula (Nordmann,, 1832) & Carassius gibelio & Cakic et al., 1998 \\
\hline Cestoda & Triaenophorus nodulosus (Pallas, 1781) & Ctenopharyngodon idella & Cakic and Hristic, 1987 \\
\hline \multirow{4}{*}{ Nematoda } & Philometroides cyprini (Ishii, 1931)* & Carassius gibelio & Cakic et al., 1998 \\
\hline & Philometroides parasiluri (Yamaguti, 1935)* & Percottus glenii & Nikolic et al., 2007 \\
\hline & Schulmanela petruschewskii (Schulman, 1948) & Lepomis gibbosus & Peric, 1994 \\
\hline & Eustrongylides sp. (Jägerskiöld, 1909)* & Percotus glenii & $\begin{array}{c}\text { Moravec, } 2008 \\
\text { (Nikolic et al., 2007) }\end{array}$ \\
\hline \multirow{6}{*}{ Acanthocephala } & Acanthocephalus anqullae (Müller, 1780) & $\begin{array}{l}\text { Oncorhynchus mykiss } \\
\text { Ameiurus nebulosus }\end{array}$ & Cakic, 2002 \\
\hline & Neoechinorhynchus rutili (Müller, 1780) & \multirow{5}{*}{ Oncorhynchus mykiss } & Cakic and Hristic, 1987 \\
\hline & Pomphorhynchus laevis (Müller, 1776) & & Babic, 1935 \\
\hline & $\begin{array}{l}\text { Pomphorhynchus bosniacus (Kiskarolj \& } \\
\text { Cankovic, 1969) }\end{array}$ & & Cakic, 2002 \\
\hline & Metechinorhynchus salmonis (Muller, 1780) & & Cakic, 2002 \\
\hline & Pseudoechinorhynchus borealis (Linstow, 1901 & & Cakic, 2002 \\
\hline Hirudinea & Piscicola geometra (Linnaeus, 1758) & Carassius gibelio & Cakic et al., 1998 \\
\hline & Ergasilus sieboldi (von Nordmann, 1832)* & $\begin{array}{c}\text { Ctenopharyngodon idella } \\
\text { Lepomis gibbosus }\end{array}$ & Cakic and Hristic, 1987 \\
\hline Crustacea & Lernaea cyprinacea (Linnaeus, 1758)* & $\begin{array}{c}\text { Hypophthalmichthys molitrix } \\
\text { Lepomis gibbosus }\end{array}$ & $\begin{array}{l}\text { Cakic and Hristic, } 1987 \\
\text { Cakic and Hristic, } 1987\end{array}$ \\
\hline & Sinergasilus polycolpus (Markevich, 1940)* & Hypophthalmichthys molitrix & $\begin{array}{c}\text { Cakic, } 1986 \\
\text { Cakic et al., } 1998\end{array}$ \\
\hline
\end{tabular}

*A new parasite species in the ichthyoparasitofauna in Serbian open waters 
Detailed data of parasite species records from seven examined invasive allochthonous fish species from Serbian open waters are presented in Table 3. Sampling localities are marked in Figure 1.

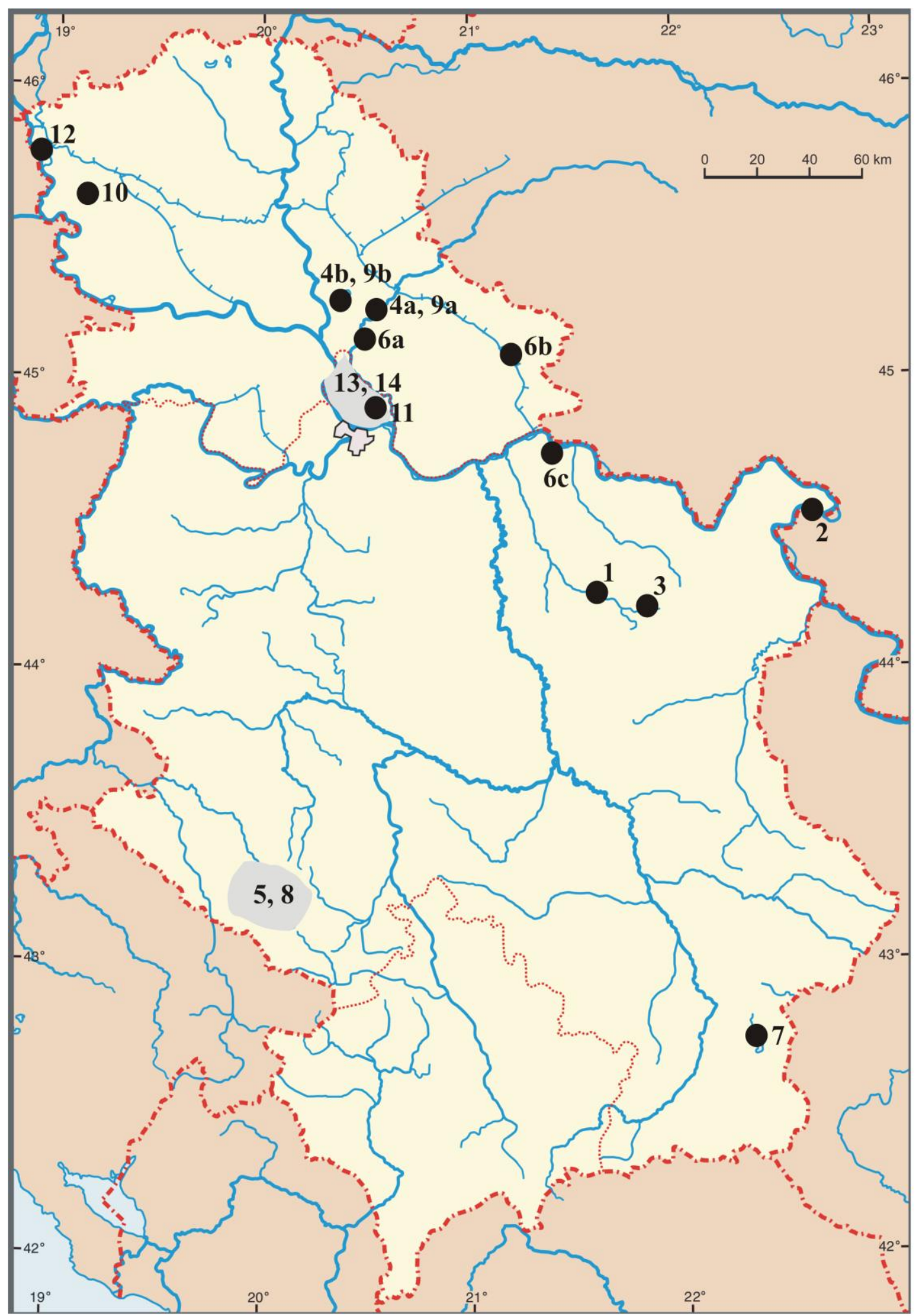

Figure 1. Map of sampling localities on Serbian surface waters. (Numbers in map are given in Table 3) 
Table 3. Details about sampling of invasive fish species and their parasites

\begin{tabular}{|c|c|c|c|}
\hline Cited reference & Sampling date and location & Symbol & GPS coordinates \\
\hline Nikolic et al., 2010 & 1998, Krepoljin & 1 & $\mathrm{~N} 44^{\circ} 16^{\prime} 0 ”$, E 2137' 0’'E \\
\hline Nikolic et al., 2007 & 2003, Vajuga near Kladovo & 2 & N 4433’15.84”, E 22³7’58.08” \\
\hline Nikolic et al., 2006 & 1998, Žagubica & 3 & 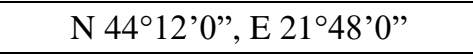 \\
\hline Nikolic et al., 2003 & 1994, (a)Uzdin and (b)Ečka & 4 &  \\
\hline Cakic, 2002 & $\begin{array}{c}\text { October } 1986 \text { - May 1989, Uvac } \\
\text { river basin on Sjenica-Pešter } \\
\text { plateau }\end{array}$ & 5 & $\mathrm{~N} 43^{\circ}-43^{\circ} 30^{\prime}$, E $19^{\circ} 45^{\prime}-20^{\circ} 15^{\prime}$ \\
\hline $\begin{array}{l}\text { Nikolic and Simonovic, } \\
1999 \mathrm{a}\end{array}$ & $\begin{array}{l}\text { 1991-1998, (a)Baranda } \\
\text { (b)Vršački ritovi } \\
\text { (c)Silver lake }\end{array}$ & 6 &  \\
\hline $\begin{array}{l}\text { Nikolic and Simonovic, } \\
1999 \mathrm{~b}\end{array}$ & 1993, Vlasina lake & 7 & $\mathrm{~N} 42^{\circ} 42^{\prime}$, E $22^{\circ} 20^{\prime}$ \\
\hline Cakic et al., 1998 & $\begin{array}{c}\text { October } 1986 \text { - May } 1989, \\
\text { waters of Sjenica-Pešter plateau }\end{array}$ & 8 & $\mathrm{~N} 43^{\circ}-43^{\circ} 30^{\prime}$, E $19^{\circ} 45^{\prime}-20^{\circ} 15^{\prime}$ \\
\hline $\begin{array}{c}\text { Nikolic and Simonovic, } \\
1998 \mathrm{a}\end{array}$ & 1994, (a)Uzdin and (b)Ečka & 9 &  \\
\hline $\begin{array}{l}\text { Nikolic and Simonovic, } \\
1998 \mathrm{~b}\end{array}$ & 1995, Svilojevo & 10 & N 45³9', E 194' \\
\hline Peric, 1994 & $\begin{array}{l}\text { 1993, Sibnica channel } \\
\text { (Pancevacki rit wetland) }\end{array}$ & 11 & N 414’12”, E 30 8'59.99”, \\
\hline Kiskaroly and Tafro, 1988 & $\begin{array}{l}\text { 1985-1987, Danube river } \\
\text { (Channel system DTD) }\end{array}$ & 12 & $\mathrm{~N} 45^{\circ} 45^{\prime} 27.24^{\prime \prime}$, E $19^{\circ} 0^{\prime} 35.96^{\prime \prime}$ \\
\hline Cakic and Hristic, 1987 & $\begin{array}{c}\text { 1984-1985, lowland channels of } \\
\text { Pancevacki rit wetland }\end{array}$ & 13 &  \\
\hline Cakic, 1986 & $\begin{array}{c}\text { 1984-1985, waters of } \\
\text { Pancevacki rit channels }\end{array}$ & 14 &  \\
\hline Babic, 1935 & $\begin{array}{l}\text { Serbian part of Danube and } \\
\text { Sava rivers }\end{array}$ & & \\
\hline
\end{tabular}

\section{Discussion}

The Danube River is one of the main target areas for invasive fish species, as well as one of the most convenient ways for their dispersal. In the Danube River drainage area in Serbia 26 non-indigenous fishes have been recorded (Maletin et al., 1997; Simonovic and Nikolic, 1997; Simonovic, 2006).

One of the most adverse effects of the introduction of non-indigenous fish species on the native ones is associated with the introduction of exotic parasitic species. The unfavorable consequences of parasitism related with introduction of non-native fish species and spreading of parasites to native taxa have already been reported in Serbia (Cakic and Hristic, 1987; Cakic et al., 1998, 2001, 2004; Nikolic and Simonovic, 1998a,b, 1999a,b; Nikolic et al., 2003, 2006, 2007, 2010).

According to previous investigations in Serbia, the fish parasite fauna was supplemented by Trichodina nobilis (Ciliata), Triaenophorus nodulosus (Pallas, 1781) (Cestoda) and Philometroides cyprini (Nematoda) after the deliberate introduction of Asian fish species, such as Grass carp Ctenopharyngodon idella, Bighead carp Hypophthalmichthys nobilis (Richardson, 1845), silver carp Hypophthalmichthys 
mollitrix (Valenciennes, 1844) into fish farms (Nikolic and Simonovic, 1998a) and invasion by Philometroides parasiluri (Yamaguti, 1935) and Eustrongylides sp. (Jägerskiöld, 1909) from P. glenii (Nikolic et al., 2007). Comparing with the results reported for the last 70 years (Djikanovic et al., 2012), eight parasitic species found in allochthonous fish are new for parasitofauna in the Serbian open water.

Ectoparasites of allochthonous fish species in Serbian open waters are examined. They can be detected as an outcome of fish juveniles' introduction or together with alien fish species. With fish juveniles several Asiatic ectoparasitic species were imported from the family of Trichodinidae, as a consequence of fish introduction in fishponds without previous health condition control (Nikolic and Simonovic, 1998a,b; Nikolic et al., 2007).

Endoparasites of allochthonous fish species in Serbian open waters have been the subject of a few hydrobiological investigations (Cakic et al., 1998, 2001, 2004). In relation to the growing concern about biological invasions in the Serbian section of the Danube River and interconnected ecosystems (Cakic et al., 1998, 2001, 2004; Simonovic et al., 1998, 2001; Simonovic, 2006) this work provides worthy information on the parasitofauna of non-indigenous fish species.

Metazoan parasites of Neogobius fishes (monkey goby Neogobius fluviatilis (Pallas, 1814), bighead goby Ponticola kessleri (Günther, 1861) and round goby Neogobius melanostomus (Pallas, 1814)) have been investigated in the Slovak section of the Danube River. Thirteen parasite species were identified, and the most prevalent parasites were Pomphorhynchus laevis (Acanthocephala) and glochidia of Anodonta anatine. The maximum parasite diversity was found in N. fluviatilis (Ondračkova et al., 2005). These founds are common to parasites in the Middle Danube basin. Gobiid fish (Neogobius melanostomus and N. fluviatilis) from the north-western Black Sea were analysed for presence of helminth species, and representatives from Cestoda (1), Trematoda (6), Nematoda (6) and Acanthocephala (3) have been reported (Kvach, 2005). In Serbian open waters no parasites for Neogobius fishes were observed. Parasitofauna of gobiid species in the Serbian part of the Danube River has not been investigated yet.

In the brown bullhead Ameiurus nebulosus some Trematodes from family Allocreadiinae and a few helminth parasites were found in the USA (Arnold, 1934; Krueger, 1954), while in the Serbian section of the Danube ectoparasites from the group Cliophora and Acanthocephalus anguillae (Acanthocephala) (Cakic and Hristic, 1987; Kiskaroly and Tafro, 1988; Nikolic and Simonovic, 1998b, 1999a,b; Nikolic et al., 2003) have been recorded. Piscicola geometra (Hirudinea) was recorded in Prussian carp Carassius gibelio (Bloch, 1782) from a lake in Turkey (Arslan and Emiroglu, 2011). Prussian carp from the Srebarna Biosphere Reserve was infected with two trematode species (Posthodiplostomum cuticola and Diplostomum rutili) and two nematode species (Contracaecum microcephalum and Raphidascaris acus) (Shukerova, 2005). In the Serbian open waters, Prussian carp have been infected by Posthodiplostomum cuticula and Philometroides cyprinid and some ectoparasites (Ciliophora) (Cakic and Hristic, 1987; Nikolic and Simonovic, 1998a,b; Cakic et al., 2001; Nikolic et al., 2003, 2006).

Some Monogenean parasites (Dactylogyrus suchengtai, D. hypophthalmichthys and D. scrjabini) were recovered from the silver carp at a fish farm in Hungary (Molnar, 1984). In our study, one Ciliophora and two crustaceans were found for this fish (Cakic and Hristic, 1987; Cakic et al., 1998; Nikolic and Simonovic, 1998a). Intestinal lesions 
in the Grass carp caused by infection of Balantidium ctenopharyngodonis (Protozoa: Ciliophora) were reported by Molnar and Reinhardt (1978). Species Trichodina nobilis, Ergasilus sieboldi and Triaenophorus nodulosus have been detected in this alien fish species in the Serbian section of the Danube River Basin (Nikolic and Simonovic, 1998a).

During the survey in Denmark, the Rainbow trout Oncorhynchus mykiss has been examined and 12 protozoans and 10 metazoan species were found (Buchmann and Bresciani, 1997). In Serbian surface waters, a diverse parasitofauna of rainbow trout has been detected (Babic, 1935; Cakic, 1992; Nikolic and Simonovic, 1999a,b; Nikolic et al., 2006, 2010). Helminth fauna of the Chinese sleeper (Nippotaenia mogurndae, Asymphylodora sp.) and Lepomis gibbosus (Triaenophorus nodulosus, Proteocephalus percae, Echinorhynchidae) have been reported (Košuthová et al., 2009). Two monogenean parasites were found on the gill filaments of the pumpkinseed Lepomis gibbosus (Linnaeus, 1758) (Sterud and Jorgensen, 2006). Some monogenean parasites of pumpkinseed from the Slovak part of the Danube River Basin have been collected (Gyrodactylus sp., Onchocleidus similis, O. dispar and Actinocleidus recurvatus) (Ondračková et al., 2011). Monogenea Urocleidus similes, Nematoda Schulmanela petruschewskii, two crustaceans (Ergasilus sieboldi, Lernaea cyprinacea) as well as one species from Ciliophora (Trichodinella epizootica) were identified for Lepomis gibbosus in our study (Cakic and Hristic, 1987; Kiskaroly and Tafro, 1988; Cakic et al., 1998; Nikolic and Simonovic, 1999a).

The cestode Nippotaenia mogurndae is reported for the Chinese sleeper Perccottus glenii (Perciformes: Odontobutidae) (Košuthová et al., 2004; Reshetnikov et al., 2011). Except this cestoda species, the parasite community consisted of Trichodina domerguei and of 3 species, Diplostomum spathaceum (metacercaria), Echinochasmus spinosus (met.), and Eustrongylides excisus (larvae) (Mierzejewska et al., 2012). The parasites of the Perccottus glenii were studied in different parts of Ukraine and 15 taxa of parasites were registered; among them were 1 species of Microsporidia, 5 species of ciliates, 2 species of cestodes, 2 species of trematodes, 2 species of nematodes, 1 species of acanthocephalan, 1 species of parasitic crustacean and 1 mollusk (glochidia) (Kvach et al., 2013). For this alien fish, two Nematodes have been recorded in Serbian open waters (Philometroides parasiluri, Eustrongylides sp.) (Nikolic et al., 2007; Moravec, 2008).

Generally, the helminth fauna of invasive fish species reported from the new territories is less rich than their native areas (Drake, 2003; Torchin et al., 2003).

The consequences of introducing pathogens or hosts into new geographical zones where certain parasites exist can affect the healthiness of native fish population (Blanc, 2001; Pegg et al., 2015). The impacts of alien fish introduction on the fish populations in open waters are several: Demographic impacts (the impacts on the survival of fish populations are rarely quantified, except in the particular case of lake ecosystems, or populations targeted for fishing or long-term scientific studies); Genetic impacts (genetic differences of the hosts could play a critical role in the nature and outcome of helminthiasis - Wakelin (1978, 1992), hybridization was also considered with introgression of the resistance character or selective rearing of the survivors of a given population (Blanc, 2001). One of the negative impacts of alien species on freshwater ecosystems is the introduction of alien infectious agents, representing one of the greatest risks associated with ecological implications of introduction of species (Britton, 2013; Britton et al., 2011). As such, topmouth gudgeon in Europe is a carrier of several 
pathogens (Gozlan et al., 2005), posing a risk not only to freshwater aquatic species, as this threat has also expanded to marine fishes.

Usually, invasive species have less parasite richness than in their native habitats (Torchin et al., 2003). The release of parasites and pathogens is one of the conditions of successful invasion (Kvach et al., 2013).

\section{Conclusion}

The large presence of alien fish species and its parasites creates a serious threat for the stability of freshwater ecosystems and the survival of the native ichthyofauna. In the Serbian surface waters contribution of allochthonous fish species to the total species richness of ichthyofauna is $27.66 \%$. Invasive species are often superior competitors in relation to the evolutionary isolated native species populations (Mills et al., 2004). Negative impacts on native species include predation, trophic competition, behavioural interference, hybridization, spread of novel parasites and diseases, alteration of food webs and modification of biochemical cycles (Mills et al., 2004; Cucherousset and Olden, 2011; Kalogianni et al., 2014).

Invasion of allochthonous fishes in the Danube River Basin in Serbia caused important changes in the native fish fauna composition and also enriched the fish parasite fauna.

Acknowledgements. This work is supported by Ministry of Education, Science and Technological Development of the Republic of Serbia, Projects No. 173045 and No. 173025.

\section{REFERENCES}

[1] Arnold, G. J. (1934): Some trematodes of the common bullhead Ameiurus nebulosus (Le Sueur). - Transactions of the American Microscopical Society 53(3): 267-276.

[2] Arslan, N., Emiroglu, Ö. (2011): First record of parasitic Annelida-Hirudinea (Piscicola geometra Linnaeus, 1761) on Carassius gibelio (Bloch, 1782) in Lake Uluabat (Turkey). - Kafkas Universitesi Veteriner Fakultesi Dergisi 17(1): 131-133.

[3] Babic, I. (1935): Records of endoparasites in freshwater fishes. - Veterinary Archiv 5(8): 356-367.

[4] Banina, N. N. (1984): Order: Peritrichida. Suborder: Sessilina. - In: Shulman, S. S. (ed.) Key to Parasites of Freshwater Fish of USSR. Zoologicheskij Institut, Leningrad, pp. 281-321.

[5] Bauer, O. N. (1987): The Guide for Identification of Parasites of Freshwater. Fish Fauna of SSSR, Tom III. - Akademiya Nauk SSSR, Zoologicheskij Institut, Leningrad.

[6] Blanc, G. (2001): Introduction of Pathogens in European Aquatic Ecosystems: Attempt of Evaluation and Realities. - In: Uriarte, A., Basurco, B. (eds.) Environmental Impact Assessment of Mediterranean Aquaculture Farms. CIHEAM, Zaragoza, Spain, pp. 37-56.

[7] Bornø, G., Colquhoun, D. (2009): Classical Furunculosis (in Norwegian). Fact Sheet. Norwegian Veterinary Institute. http://www.vetinst.no/nor/Faktabank/Allefaktaark/Furunkulose-klassisk.

[8] Britton, J. R. (2013): Introduced parasites in food webs: new species, shifting structures? - Trends Ecol. Evol. 28: 93-99.

[9] Britton, J. R., Pegg, J., Williams, C. F. (2011): Pathological and ecological host consequences of infection by an introduced fish parasite. - PLoS One 6(10): e26365. 
[10] Buchmann, K., Bresciani, J. (1997): Parasitic infections in pond-reared rainbow trout Oncorhynchus mykiss in Denmark. - Diseases of Aquatic Organisms 28: 125-138.

[11] Bykhovskaya-Pavlovskaya, I. E., Gusev, A. V., Dubinina, M. N. et al. (1962): The guide for Determination of Parasites of Fresh Water Fish of SSSR. - Akademiya Nauk SSSR. Zoologicheskij Institut, Leningrad.

[12] Cakic, P. (1992): Fish parasites in waters of Sjenicko-Pesterska plateau and possibilities of their decrease. - Dissertation, University of Belgrade.

[13] Cakic, P., Hristic, D. J. (1987): Ichthyofauna of Pancevacki rit channels with regard to alochthonous species. - Natural Museum B42: 103-118.

[14] Cakic, P., Kataranovski, D., Milutinovic, M. (1996): Ancyrocephalus paradoxus Creplin, 1839 (Monogenea), a new species for ichthyoparasitofauna of Yugoslavia. - Proceedings of 7th International Congress on the Zoogeography and Ecology of Greece and Adjacent Regions, Book of abstracts, Athens, Greece.

[15] Cakic, P., Petrovic, Z., Kataranovski, D., Fister, S. (1998): Detection of parasitic copepods Lamproglena pulcella (Nordmann, 1983) and Lernaea cyprinacea (Linnaeus, 1758) on the gills of fish from Yugoslav waters. - Acta Veterinaria Belgrade 48(2-3): 131-138.

[16] Cakic, P., Stojanovski, S., Kataranovsk, I. D., Fister, S. (2001): The first finding of the nematode Philometroides cyprini (Ishii, 1931) on Carassius auratus gibelio from the Danube River, Yugoslavia. - Proceedings of the Scientific Meeting "Tissue Helminthoses of Men and Animals", Belgrade, pp. 65-70.

[17] Cakic, P., Lenhardt, M., Kolarevic, J. (2004): Sinergasilus polyclopus, a new copepod species in the ichthyoparasitofauna of Serbia and Montenegro. - Diseases of Aquatic Organisms 58: 265-266.

[18] Djikanovic, V., Paunovic, M., Nikolic, V., Simonovic, P., Cakic, P. (2012): Parasitofauna of freshwater fishes in the Serbian open waters: a checklist of parasites of freshwater fishes in Serbian open waters. - Reviews in Fish Biology and Fisheries 22(1): 297-324.

[19] Drake, J. M. (2003): The paradox of the parasites: implications for biological invasion. Proceeding of the Royal society of London Series B, Biological Sciences 270: S133S135.

[20] Elvira, B. (2001): Identification of non-native freshwater fishes established in Europe and assessment of their potential threats to the biological diversity. - Document on the $21^{\text {st }}$ Meeting of the Standing Committee of the Convention of the Conservation of European Wildlife and Natural Habitats. Strasbourg, pp. 1-35.

[21] Galil, B. S., Nehring, S., Panov, V. E. (2007): Waterways as Invasion Highways. Impact of Climate Change and Globalization. - In: Nentwig, W. (ed.) Ecological Studies, Biological Invasions No 193. Springer, Berlin, pp. 59-74.

[22] Gherardi, F., Gollasch, S., Minchin, D., Olenin, S., Panov, V. (2009): Alien Invertebrates and Fish in European Inland Waters. - In: Drake. J. A. (ed.) DAISIE. Handbook of Alien Species in Europe. Springer, Knoxville, pp. 81-92.

[23] Grigorovich, I. A., Colautti, R. I., Mills, E. L., Holeck, K., Ballert, A. G., MacIsaac, H. J. (2003): Ballast-mediated animal introductions in the Laurentian Great Lakes: retrospective and prospective analyses. - Canadian Journal of Fish Aquatic Science 60: 740-756.

[24] Hegedis, A., Nikcevic, M., Mickovic, B., Jankovic, D., Andjus, R. K. (1991): Discovery of the goby Neogobius gymnotrachelus in Yugoslav fresh waters. - Archives of Biological Sciences 43: 39-40.

[25] Hoffman, G. L., Schubert, G. (1984): Some Parasites of Exotic Fishes. - In: Courtney, W. R. Jr., Stauffer, J. R. Jr. (eds.) Distribution, Biology and Management of Exotic Fishes. Johns Hopkins University Press, Baltimore, pp 233-261.

[26] Jackson, M. C., Britton, J. R. (2014): Divergence in the trophic niche of sympatric freshwater invaders. - Biological Invasions 16(5): 1095-1103. 
[27] Jankovic, D. (1998): Natural reproduction by Asiatic herbivorous fishes in the Yugoslav section of the River Danube. - Italian Journal of Zoology 65: 227-228.

[28] Jankovic, D., Hegedis, A., Krpo, J. (1987): Taxonomische und Okologosche Charakteristiken des Gobius (Neogobius) fluviatils Pallas (1811) im Jugoslawischen Donauteil. - Proceedings of 26. Arbeitstagung der IAD, Passau, Deutschland, pp. 266269.

[29] Kiskaroly, M., Tafro, A. (1988): The contribution of knowledge of helminthofauna of some fishes in one part of the Danube River. - Veterinaria 37(2-3): 211-221.

[30] Košuthová, L., Letková, V., Koščo, J., Košuth, P. (2004): First record of Nippotaenia mogurndae Yamaguti and Miyata, 1940 (Cestoda: Nippotaeniidae), a parasite of Perccottus glenii Dybowski, 1877, from Europe. - Helminthologia 4: 55-57.

[31] Košuthová, L., Koščo, J., Letkova, V., Košuth, P., Manko, P. (2009): New records of endoparasitic helminths in alien invasive fishes from the Carpathian region. - Biologia 64(4): 776-780.

[32] Krueger, R. F. (1954): A survey of the helminth parasites of fishes from Van Buren lake and rocky ford Greek. - The Ohio Journal of Science 54(4): 277-279.

[33] Kvach, Y. (2005): A comparative analysis of helminth faunas. And infection parameters of ten species of gobiid fishes (Actinipterygii: Gobiidae) from the north-western Black Sea. - Acta Ichthyologica et Piscatoria 35(2): 103-110.

[34] Kvach, Y., Drobiniak, O., Kutsokon, Y., Hoch, I. (2013): The parasites of the invasive Chinese sleeper Perccottus glenii (Fam. Odontobutidae), with the first report of Nippotaenia mogurndae in Ukraine. - Knowledge and Management in Aquatic Ecosystems 409(05): 1-11.

[35] Labaude, S., Rigaud, T., Cézilly, F. (2015): Host manipulation in the face of environmental changes: Ecological consequences. - International Journal for Parasitology: Parasites and Wildlife 4: 442-451.

[36] Lenhardt, M., Markovic, G., Hegedis, A., Maletin, S., Cirkovic, M., Markovic, Z. (2011): Non-native and translocated fish species in Serbia and their impact on the native ichthyofauna. - Reviews in Fish Biology and Fisheries 21: 407-421.

[37] Lom, J., Dykova, I. (1992): Protozoan parasites of fishes. Developments in Aquaculture and Fisheries Science 26. - Elsevier Science Publishers B. V., Amsterdam.

[38] Mack, R. N., Simberloff, D, Lonsdale, W. M., Evans, H., Clout, M., Bazzaz, F. A. (2000): Biotic invasions: causes, epidemiology, global consequences, and control. Ecological Applications 10: 689-710.

[39] Maletin, S., Djukic, N., Miljanovic, B., Ivanc, A. (1997): Status of allochthonous ichthyofauna of Panonian Basin in Yugoslavia. - Acta Biologica Iugoslavica - Ecology 32(2): 87-98.

[40] Mierzejewska, K., Kvach, Y., Woźniak, M., Kosowska, A., Dziekońska-Rynko, J. (2012): Parasites of an Asian fish, the Chinese sleeper Perccottus glenii, in the Włocławek Reservoir on the lower Vistula River, Poland: Search of the key species in the host expansion process. - Comparative Parasitology 79(1): 23-29.

[41] Molnar, K. (1984): Occurrence of new monogeneans of Far-East origin on the gills of fishes in Hungary. - Acta Veterinaria Hungarica 32(3/4): 153-157.

[42] Molnar, K., Reinhardt, M. (1978): Intestinal lesions in grass carp Ctenopharyngodon idella (Valenciennes) infected with Balantidium ctenopharyngodonis Chen. - Journal of Fish Diseases 1(2): 151-156.

[43] Moravec, F. (1994): Parasitic Nematodes of Freshwater Fishes of Europe. - Kluwer Acad. Publ., Dordrecht, pp. 172-173, 195-198, 377-380, 396-399.

[44] Moravec, F. (2008): Misidentification of nematodes from the Chinese sleeper in Europe. - Bulletin of the European Association of Fish Pathologists 28(2): 86-87.

[45] Nikolic, P. V., Simonovic, P. D. (1998a): Seasonal dynamics of carp infestation by Trichodina nobilis Chen, 1963 (Peritrichia, Ciliata) in two fish-ponds in Banat. - Tiscia Szeged 31: 59-61. 
[46] Nikolic, P. V., Simonovic, D. P. (1998b): Trichodinella epizootica (Raabe, 1950) (Protozoa: Ciliata) - a new species for the Yugoslav fish-parasite fauna. - Ichthyologia 30(1): 39-41.

[47] Nikolic, P. V., Simonovic, D. P. (1999a): A survey of ciliate fish-parasite fauna of Yugoslavia. - Ichthyologia 31(1): 37-41.

[48] Nikolic, P. V., Simonovic, P. (1999b): Ciliata parasitofauna of fish in fishponds and open waters of Yugoslavia. - Proceedings of the Environmental Protection in Intensive Fish farming Workshop '97, Novi Sad, pp. 96-101.

[49] Nikolic, P. V., Simonovic, P., Poleksic, V. (2003): Preference of trichodinids (Ciliata, Peritrichia) occuring on fish-pond carp for particular organs and some morphological implications. - Acta Veterinaria Belgrade 53(1): 41-46.

[50] Nikolic, P. V., Simonovic, P. D., Maric, S. P. (2006): Occurrence of Chilodonella hexasticha (Ciliophora, Protista) on the farmed rainbow trout Oncorhynchus mykiss through the season. - Acta Veterinaria Belgrade 56(1): 55-61.

[51] Nikolic, P. V., Simonovic, P., Karan Znidarsic, T. (2007): First record in Europe of a nematode parasite in Amur sleeper Perccottus glenii Dybowski 1877 (Perciformes, Odontobutidae). - Bulletin of the European Association of Fish Pathologists 27: 36-38.

[52] Nikolic, P. V., Djikanovic, V., Paunovic, M., Maric, S., Simonovic, P. (2010): Parasitic infections in pond-reared rainbow trout Oncorhynchus mykiss in eastern Serbia. Proceedings of the $1^{\text {st }}$ International Symposium of Fisheries and Fishing Tourism, June 2010. Center for Fisheries "Neretva" Konjic, Boracko Lake, Bosnia and Herzegovina, pp. 245-247.

[53] Ondračková, M., Dávidová, M., Pečínková, M. et al. (2005): Metazoan parasites of Neogobius fishes in the Slovak section of the River Danube. - Journal of Applied Ichthyology 21: 345-349.

[54] Ondračková, M., Dávidová, M., Přikrylová, I., Pečínková, M. (2011): Monogenean parasites of introduced pumpkinseed Lepomis gibbosus (Centrarchidae) in the Danube River Basin. - Journal of Helminthology 85(4): 435-441.

[55] Pegg, J., Andreou, D., Williams, C. F., Britton, J. R. (2015): Temporal changes in growth, condition and trophic niche in juvenile Cyprinus carpio infected with a non-native parasite. - Parasitology 142(13): 1579-1587.

[56] Peric Z (1994): Dynamic of fish endoparasites appearance in open waters, as well as criterions for their repression. - Msc Thesis, Faculty of Veterinary Medicine, University of Belgrade.

[57] Reshetnikov, A. N., Protasova, E. N., Sokolov, S. G., Pelgunov, A. N., Voropaeva, E. L. (2011): Infection of Perccottus Glenii Dybowski, 1877 (Odontobutidae, Pisces) by parasite Nippotaenia Mogurndae Yamaguti et Miyata, 1940 (Nippotaeniidae, Cestoda) through cannibalism. - Russian Journal of Biological Invasions 2(1): 46-48.

[58] Shukerova, S. (2005): Helminth fauna of the Prussian carp, Carassius gibelio (Bloch, 1782), from the Srebarna Biosphere reserve. - Trakia Journal of Sciences 3(6): 36-40.

[59] Shulman, S. S., Jankovsky, A. V. (1984): Phylum Ciliophora. - In: Shulman, S. S. (ed.) Key to Parasites of Freshwater Fish of USSR. Zoologicheskij Institut, Leningrad, pp. 225-280.

[60] Simonovic, P. (2006): The Fishes in Serbia. 2nd edition. - NNK International, Faculty of Biology \& Agency for Environment Protection, Belgrade, Serbia.

[61] Simonovic, P., Nikolic, V. (1997): Freshwater fish of Serbia: an annotated check list with some faunistic and zoogeographic considerations. - Bios Thessaloniki 4: 137-156.

[62] Simonovic, P., Valkovic, B., Paunovic, M. (1998): Round goby Neogobius melanostomus, a new Ponto-Caspian element for Yugoslavia. - Folia Zoologica 47(4): 305-312.

[63] Simonovic, P., Paunovic, M., Popovic, S. (2001): Morphology, feeding and reproduction of the round goby, Neogobius melanostomus (Pallas), in the Danube River basin, Yugoslavia. - Journal of Great Lakes Research 27(3): 281-289. 
[64] Stein, G. A. (1984): Order Peritrichida. Suborder Mobilina. - In: Shulman, S. S. (ed.) Key to Parasites of Freshwater Fishes of the USSR. Zoologicheskij Institut, Leningrad, pp. 321-389.

[65] Sterud, E., Jorgensen, A. (2006): Pumpkinseed Lepomis gibbosus (Linnaeus, 1758) (Centrarchidae) and associated parasites introduced to Norway. - Aquatic Invasions 1(4): 278-280.

[66] Stewart, J. E. (1991): Introductions as factors in diseases of fish and aquatic invertebrates. - Canadian Journal of Fisheries and Aquatic Sciences 48: 110-117.

[67] Torchin, M. E., Lafferty, K. D., Kuris, A. M. (2001): Release from parasites as natural enemies: increased performance of a globally introduced marine crab. - Biology Invasions 3: 333-345.

[68] Torchin, M. E., Lafferty, K. D., Dobson, A. P., McKenzie, V. J., Kuris, A. M. (2003): Introduced species and their missing parasites. - Nature 421: 628-630.

[69] Wakelin, D. (1978): Genetic control of susceptibility and resistance to parasitic infections. - Advances in Parasitology 16: 219-308.

[70] Wakelin, D. (1992): Genetic variation in resistance to parasitic infection: experimental approaches and practical applications. - Research in Veterinary Science 53: 139-147.

[71] Welcomme, R. L. (1981): Register of International Transfers of Inland Fish Species. FAO Fisheries Technical Paper, Rome.

[72] Welcomme, R. L. (1988): International Introductions of Inland Aquatic Species. - FAO Fish. Tech. Pap. 294: 318, Rome.

[73] Zorić, K., Simonović, P., Djikanović, V., Marković, V., Nikolić, V., Simić, V., Paunović, M. (2014): Checklist of non-indigenous fish species of the River Danube. - Archives of Biological Sciences 66(2): 629-639. 